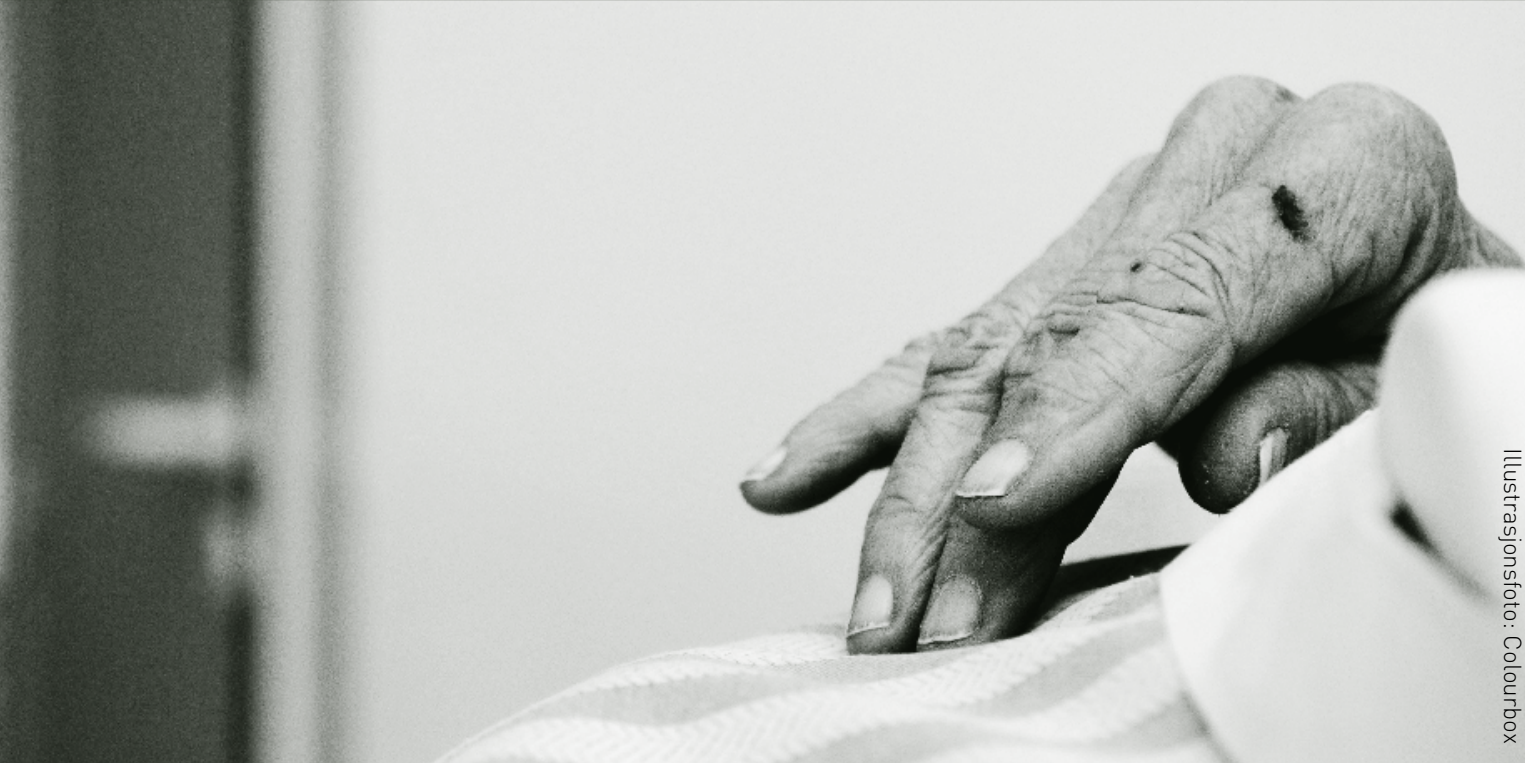

Bakgrunn: Samhandlingsreformen ble iverksatt 1/1-12. Samtidig trådte forskriften om kommunal medfinansiering og kommunal betaling for utskrivningsklare pasienter i kraft. Kommunene overtok derved det finansielle ansvaret for utskrivningsklare pasienter på sykehus fra første dag.

Hensikt: Undersøke virkningene i kommunene av forskriften om kommunal medfinansiering

Metode: Feltstudie med intervju av ledende helsepersonell og undersøkelse av lokale dokumenter ble gjennomført av 67 siste års medisi- nerstudenter utplassert i 40 kommuner i seks uker. Det var på forhånd utarbeidet en semistrukturert intervjuguide. Studentene leverte en tre til fem siders rapport i henhold til en mal som er blitt analysert og validert.

Resultater: I de fleste kommunene kom det frem at pasienter kommer tidligere enn før og det er blitt flere. Mange kommuner har prioritert utskrivningsklare pasienter ved å øke kapasiteten eller omgjøre institusjonsplasser. Det har gjort det vanskeligere for andre i kommunen å få sykehjemsplass eller korttidsopphold. Mange steder var det opprettet et nytt mottaks-og tildelerapparat.
Mengden administrativt arbeid har øt og funnene indikerer at enkelte pasienter får et mer oppstykket forŁøp. Helsepersonell i noen kommuner har reagert positivt på de økte utfordringene med sykere pasienter.

Konklusjon: Innføring av kommunal medfinansiering av utskrivningsklare pasienter har virket effektivt og har redusert antallet dager pasienter venter på et kommunalt tilbud. Funn i studien og internasjonal forskning reiser imidlertid tvil om den økte bruken av institusjoner i mottak av utskrivningsklare pasienter er en riktig utvikling i møte med fremtidige behov.
What happens when municipalities are charged for patients waiting in hospitals for proper primary care to be established?

Background: A care coordination reform was effectuated January 1 , 2012. At the same time, the municipals responsible for primary care in Norway became financially responsible for patients in the hospitals ready to be discharged but waiting for a bed in a nursing home or home care services. Objective: To study the effect of the new financial regulations for waiting patients ready to be discharged

Method: 67 upper-level medical students visting 40 municipalities in six weeks carried out a field study with interviews of management personnel and an analysis of local documents. A semi-structured interview guide was prepared, and each student delivered a 3-5 pages report that was analysed and validated.

Results: In most municipalities it was reported that patients arrived earlier than before and were in a worse condition. Many municipalities had prioritized the patients reported from the hospital as ready to be discharged by increasing the capacity or rearranging beds in local institutions. Other patients living at home with corresponding needs were overlooked to a greater extent. More administrative work was reported, and some patients experi- enced less continuity. Some health personnel in the municipalities reacted positively to the presence of more challenging patients.

Conclusion: The introduction of municipal financial responsibility for waiting patients in hospital has been effective. The number of days patients in hospital have to wait for appropriate primary care services has been reduced. However, this study and international research questions of increased use of institutional community care is the best way to meet future needs.

Key words: Care coordination, primary health care, nursing home, home care services, integrated care. 


\section{Hvordan har kommunene lost utfordringen med utskrivningsklare pasienter?}

Forfatter: Anders Grimsmo

\section{NøKKELORD}

- Samhandling

- Kommunehelsetjeneste

- Organisering

- Sykehjem

- Hjemmesykepleie

\section{BAKGRUNN}

Før samhandlingsformen $(1,2)$ trådte i kraft ble utskrivningsklare pasienter liggende i sykehus i påvente av at kommunen skulle opprette et tilbud til dem. Dette hindret sykehusene i å ta inn nye pasienter, hvilket igjen forsinket og forlenget rehabilitering av mange eldre og kronisk syke. I samband med samhandlingsreformen er dette problemet forsøkt løst gjennom nye insentiver og nytt regelverk.

Den nye forskriften om kommunal medfinansiering og kommunal betaling for utskrivningsklare pasienter trådte i kraft fra 1. januar 2012 (3). Forskriften beskriver kravene til å definere en pasient som utskrivningsklar, og de plikter og oppgaver som ligger til både sykehus og kommune $\mathrm{i}$ samband med utskrivning av pasienter som trenger et kom- munalt tilbud. Kommunene overtok samtidig det finansielle ansvaret for utskrivningsklare pasienter på sykehus fra første dag. I 2009, 2010 og 2011 var det årlig registrert cirka 140.000 liggedøgn på norske sykehus av pasienter som var definert som utskrivningsklare, men som ventet på et kommunalt omsorgstilbud for å kunne skrives ut. Betalingen ble etter forhandlinger mellom Helse- og omsorgsdepartementet og KS, satt til 4000 kroner per døgn. Den årlige kostnaden på sykehus (140.000 liggedøgn x 4.000 kr) på 560 millioner kroner ble overført til kommunene fra 1/12012 (1).

Helse- og omsorgsdepartementet har gitt Norges forskningsråd i oppdrag å evaluere utviklingen i samhandlingsreformen (4). Det er foreløpig etablert tre prosjektgrupper. Studien som blir presentert her har undersøkt hvordan kommunene løste oppgaven med å ta imot utskrivningsklare pasienter det forste halve året etter at samhandlingsreformen trådte i kraft 1. januar 2012.

\section{MATERIALE OG METODE}

Studien er et ledd i en følgeevaluering. Datainnsamlingen ble organisert som en feltstudie (5). Siste året i medisinerstudiet ved NTNU blir studentene utplassert i primærhelsetjenesten i seks uker. De observerer og deltar i de viktigste aktivitetene i kommunehelsetjenesten for å få innsikt i og forståelse av hvordan primærhelsetjenesten fungerer i praksis. De møter pasienter og blir veiledet av helsepersonell. Det skjer blant annet på legekontor, i sykebesøk, på sykehjem, ved hjemmebesøk med hjemmesykepleien, deltakelse i tverrfaglige møter, med mere. Ved utplasseringen får de samfunnsmedisinske oppgaver som de må utrede og levere mens de er i kommunen. De er utplassert i et tilnærmet

\section{Hva tilfører artikkelen?}

Artikkelen viser at tiltakene som er iverksatt for å redusere antall pasienter som blir liggende i sykehus i påvente av et tilbud i kommunene, ser ut til å være effektive.

\section{Mer om forfatteren:}

Anders Grimsmo er dr.med, og professor ved Institutt for samfunnsmedisin, NTNU. Kontakt: anders.grimsmola ntnu.no. 
fast utvalg av kommuner i MidtNorge som består av både store og små kommuner. I de største kommunene er det utplassert flere studenter. Tre kommuner tilhørende Østlandet på grensen mot Midt-Norge er også med i utvalget.

Sekstisju studenter utplassert i 40 kommuner høsten 2012 fikk som oppgave å undersøke hvordan kommunene hadde løst utfordringene knyttet til utskrivningsklare pasienter. Før utplasseringen fikk studentene utskrivningsklare pasienter, for alle studentene og lærere $\mathrm{i}$ en undervisningstime, etterfulgt av en time med felles drøfting av intervju og observasjoner.

Rapportene er siden analysert med hensyn til innhold og sammenhenger i tråd med metoder for dokumentanalyse (6). Det ble opprettet et regneark hvor omtale av hovedtemaene i intervjuguiden ble nedskrevet, kodet og sortert under hver kommune. Det ble ved samme gjennomlesning i tillegg regis-

\section{Pasientene som kommer er generelt mer pleietrengende.}

en undervisningstime med gjennomgang av det nye regelverket og intensjonene. Oppgaveteksten de fikk, var: «Hvordan har kommunene løst utfordringen med utskrivningsklare pasienter etter innføringen av samhandlingsreformen». Kartleggingen skjedde ved dybdeintervju av individuelle informanter i kommunene der studentene var utplassert og gjennomgang av eventuelle relevante kommunale dokumenter, i tillegg til det de ellers observerte og deltok i de seks ukene. Det ble laget en semistrukturert intervjuguide som de ble anbefalt å bruke. Det ble gitt råd om hvilke fagpersoner og roller som kunne ha god innsikt i problemstillingen og tilgang til relevant informasjon. De hyppigst benyttete informantene var leder(e) innenfor pleie og omsorg, kommuneoverlege og tilsynslege ved sykehjem. Besvarelsen eller feltrapporten ble levert $\mathrm{i}$ henhold til en mal og skulle være på tre til fem sider. Etter utplasseringen fikk en gruppe på seks studenter i oppgave å presentere egne og medstudenters erfaringer med trert hvilke temaer som hadde blitt rapportert uoppfordret. Rapportene ble deretter gjennomgått grundig for å finne eventuelle mønstre eller koplinger av opplysninger som kunne gi ytterligere innsikt, og for å kryssjekke i hvilken grad de andre kommunene eventuelt også hadde omtalt eller berørt de nye temaene. Til slutt ble det gjort et utvalg av de temaene som var mest relevante i forhold til hovedproblemstillingen, og foretatt en endelig gjennomlesning og kvalitetssikring av avskrivning og koding. Ved gjennomgang av offentlig statistikk ble det lagt til demografisk informasjon om hver kommune som størrelse, sentralitet, alderssammensetning, samt data om utskrivningsklare pasienter som var blitt publisert på kommunenivå (7). Dette ble brukt til å sortere innholdet etter kjennetegn ved kommunene.

Resultatene er videre blitt validert ved presentasjon av funnene i en større gruppe med 60 helsefaglige representanter fra innlandsområdet på Østlan- det tilsvarende de som ble intervjuet i Midt-Norge. Hvert funn ble presentert for seg og drøftet med gruppen om i hvilken grad det var en felles erfaring og eventuelt hva som kunne være forklaringer og sammenhenger. Deler av resultatene er som i en triangulering også blitt sammenholdt med og kontrollert i forhold til offentlig statistikk på utviklingen av Samhandlingsreformen (7).

\section{RESULTATER}

I de fleste kommunene hadde studentene blitt meddelt at det hadde vært en nedgang i antall liggedøgn på overtid i sykehus etter at Samhandlingsreformen trådte i kraft. I nesten halvparten av kommunene ble det sagt at de ikke hadde hatt overtidsdøgn i 2012. Flere av de minste kommunene hadde heller ikke tidligere hatt pasienter som har måttet vente på tilbud i kommunen. I noen kommuner ble det hevdet at det nå ble meldt flere utskrivningsklare pasienter, det vil si at det ble meldt flere pasienter som trengte et kommunalt tilbud.

I de fleste kommunene ble det gitt uttrykk overfor studentene om at liggetiden var blitt kortere for gruppen som hadde behov for kommunalt tilbud og at de ble utskrevet tidligere enn før. Det ble også hevdet at pasientene derfor var sykere nå enn før. «Kommunen har sett en endring i pasientsammensetningen på sykehjemmet etter samhandlingsreformens start. Pasientene som kommer er generelt mer pleietrengende. Prolaps- og hjertepasienter blir nå skrevet ut raskere fra sykehus, og havner på korttidsopphold på sykehjem, med et større krav til kompetanse enn tidligere» (tilsynslege sykehjem).

Det kom videre frem at det 
var flere pasienter enn tidligere med komplekse problemstillinger som nå ble utskrevet til kommunene med pågående avansert behandling (intravenøs behandling, PEG-sonde, CVK, respirator og sondeernæring). Det ble oppgitt at forandringen var størst vedrørende kirurgiske pasienter. I en kommune hevdet de også at de oftere opplevde at ikke alle eller nye problemstillinger var ferdig utredet slik forskriften krever. I to kommuner hadde det inntruffet uheldige omstendigheter med pasient og pårørende når døende pasienter var blitt meldt utskrivningsklare.

Mange av kommunene hadde opprettet en ny administrativ enhet for å håndtere mottak av utskrivningsklare pasienter som likner bestiller/utfører ordningen som hittil har vært mest utbredt i store kommuner. Enhetene hadde en 24/7-vaktordning begrunnet med at pasienter kunne bli utskrevet til alle døgnets tider. Det ble beskrevet en betydelig økt informasjonsutveksling med sykehuset. Det kunne være vanskelig å treffe den som kjente til pasienten som var meldt utskrivningsklar og dato for hjemreise kunne bli omgjort flere ganger. Noen ganger også uten at kommunen ble varslet i tide. "Det er ofte mangelfull og lite utfyllende informasjon om pasienter som utskrives, og at de ofte framstilles som mindre pleietrengende enn de viser seg å være. I tillegg estimeres antall liggedøgn på sykehus ofte for lavt, slik at plasser holdes åpne for pasienter som allikevel må ligge på sykehus over lengre tid» (leder for pleie- og omsorgstjenesten).

Det hadde blitt mye telefonering og bruk av faks. Muligheter til elektronisk mel-

dingsutveksling ble etterlyst. I noen av kommunene kom det frem at spesielt opplysninger om pasientens funksjonsevne og samsykdommer var mangelfulle. Noen mente at epikrisene var blitt mer mangelfulle enn tidligere. Utfordringen med

nene så langt har greid omstillingen like godt eller bedre enn de større kommunene. I mange av de små kommunene fortalte de riktignok at de allerede før reformen ble iverksatt hadde god kapasitet til å ta imot utskrivningsklare pasienter.

\section{Det er ofte mangelfull og lite utfyllende informasjon om pasienter som utskrives.}

utskrivningsklare pasienter var blitt møtt med utvidelse og omgjøring av institusjonsplasser. Dette omhandlet økning i korttidsplasser, omgjøring av langtidsplasser eller omgjøring av enkeltrom til tosengsrom. Noen kommuner har opprettet intermediæravdeling som mottar utskrivningsklare pasienter enten alene eller i samarbeid med andre kommuner. Kommunale plasser ved distriktsmedisinske sentre ble også benyttet ved utskrivning. I et flertall av kommunene fortalte man om lengre ventetid for hjemmeboende på sykehjemsplass og korttidsopphold fordi utskrivningsklare pasienter ble prioritert. Noen steder oppga de at de nå har fått korridorpasienter på sykehjemmet og at det var nytt. «Sykehjemmet har faktisk nå opplevd korridorpasienter, noe som var svært sjeldent før» (tilsynslege sykehjem).

En del kommuner hadde styrket hjemmetjenestene for å kunne håndtere omfordelingen. Kun én kommune fortalte om $ø k t$ utskrivning direkte til hjemmet fra sykehus. Informantene i kommunen rapporterte om suksess med oppretting av et team som selv kartla de utskrivningsklare pasientenes behov mens de var innlagt på sykehuset.

Rapportene til studentene gir et bilde av at de små kommu-
Men de hadde likevel gjennomført omorganisering, kompetansehevning og økt tverrfaglig samarbeid som også inkluderte legene. Noen informanter fra de små kommunene fortalte at de ansatte hadde reagert positivt på utfordringen med utskriving av sykere pasienter. En informant $\mathrm{i}$ en kommune fortalte at fraværet hadde gått ned. Noen mente at nye og mer utfordrende oppgaver ville bedre rekrutteringen av helsepersonell til kommunen.

\section{DISKUSJON}

Undersøkelsen forteller at de fleste kommunene har reagert raskt på virkemidlene som er iverksatt for å øke kapasiteten og evnen i kommunene til å ta imot utskrivningsklare pasienter. Dette har mange kommuner fått til ved å styrke hjemmetjenestene slik at institusjonsplasser har kunnet bli frigjort og prioritert for utskrivningsklare pasienter. Dette har imidlertid gjort det vanskeligere for andre i kommunen å få sykehjemsplass eller korttidsopphold.

\section{Forbehold og begrensninger}

Undersøkelsen er en kvalitativ studie og representerer det studentene har observert og erfart, lest seg til og fått vite ved intervju og samtaler med helseper- 
sonell ellers. Rapportene gir et innblikk i hvilke erfaringer som er gjort i kommunene, mer enn omfanget av dem (8). Ingen av dem som ble spurt om intervju nektet å være med på undersøkelsen. Nøyaktig hvem som er intervjuet i de forskjellige kommunene fremgår ikke av rapportene fordi intervjuene sikt i hva som har skjedd det første halve året av reformen. Egen erfaring med bruk av helsepersonellstudenter og andre studenter som observatører i for eksempel sykehus, er at helsepersonellstudenter gjør flere og bedre observasjoner enn andre studenter, også i forhold til de som er utdannet for kunne gjøre

\section{Noen mente at epikrisene var blitt mer mangelfulle enn tidligere.}

skulle være anonyme. Dette kom imidlertid frem i plenum etter utplasseringen om hvilke og hvor mange kilder de hadde benyttet.

De fleste kommunene som har vært med i undersøkelsen hører til i Midt-Norge. Det er lokale variasjoner og det må tas forbehold om at en del forhold kan være annerledes i andre områder av landet. Det var varierende kvalitet og dekning av temaene på det studentene leverte, slik også andre har erfart (5). Temaer som kom frem uoppfordret i flere rapporter, men som ikke ble funnet tilstrekkelig dekket til å analysere, var økonomi, og erfaringer med samarbeid knyttet til distriktsmedisinske sentra.

Noen steder er det lett å skjønne at det er referert til notater fra intervjuer. I andre sammenhenger er det usikkert om det er egne observasjoner, uformelle samtaler eller tolkninger som er notert og presentert. Styrken er imidlertid at 67 studenter har intervjuet over hundre personer (de fleste en til to personer) i sentrale roller, og snakket med mange flere. Sjanse for bias skulle derfor være liten. Ujevnheter i rapportene ble i stor grad utliknet med det høye antallet og ga samlet en rik inn- feltstudier. Helsepersonellstudenter har substanskunnskap på feltet og de skjønner rekkevidden av kommunikasjon mellom helsepersonell på en bedre måte.

Gjennomgangen av resultatene for en gruppe med 60 kommunerepresentanter fra indre del av Østlandet ga ikke holdepunkter for store regionale forskjeller. Resultatene avslørte først og fremst, i likhet med rapportene, at erfaringene i kommunene var forskjellige. Undersøkelsen ble gjennomfort $i$ en tidlig fase og funnene bærer preg av omstillingene og lokal situasjon i utgangspunktet. Observasjonstiden er sannsynligvis også en vesentlig årsak til den store variasjonen i synspunkter informantene har erfart og rapportert. Når man for eksempel bare i to kommuner forteller om uheldige omstendigheter når døende pasienter blir meldt utskrivningsklare, så er det mest et uttrykk for observasjonstiden mer enn at personell i andre kommuner ville ment noe annet hvis de hadde erfart noe liknende. Hva som blir fortalt om hva kommunene selv konkret har gjort for å møte utfordringene, er det mindre grunn til å tvile på.

\section{Samsvar med offentlig}

\section{statistikk}

Flere av de forholdene som er påpekt i rapportene, representerer utviklingstrekk og problemer som har vært der lenge. Det gjelder for eksempel at liggetiden i sykehus har blitt kortere og at kommunen får for lite informasjon (9). Spørsmålet om hvor mye som er kommet til etter 1. januar 2012, er vanskelig å slå fast ut ifra dette materialet.

Likevel, statistikk som er utarbeidet av Helsedirektoratet for å følge med på utviklingen bekrefter flere av uttalelsene i rapportene. Det har vært en tydelig nedgang $\mathrm{i}$ antallet utskrivningsklare pasienter som venter på tilbud i kommunene første og andre kvartal 2012 (7). Statistikken viser også at liggetiden som utskrivningsklar for denne gruppen har gått ned, med 2,7 dager, sammenliknet med samme periode foregående år fra 6,9 dager til 4,2 dager på landsbasis. Liggetiden som ikke utskrivningsklar har derimot holdt seg uendret på ni dager siden før reformen. Samlet kortere liggetid kan derfor være forklaringen på at personell i kommunene mener å oppleve at pasientene er sykere enn tidligere.

Statistikk fra Helsedirektoratet understøtter også at flere pasienter enn tidligere blir meldt utskrivningsklare. Publiserte tall viser at det kom en stigning i antall registrerte utskrivningsklare i tiden omkring årsskiftet 2011-2012. Det skjedde trolig en skjerping av rutinene rundt melding av utskrivningsklare pasienter i tråd med både insentiver og nytt regelverk. Man må også kunne anta at tidligere praksis med ti «karensdager» før medfinansiering trådte i kraft, bidro til 
at en del pasienter som var forventet å bli utskrevet, tidligere ikke ble registrert som utskrivningsklare. Når informantene også beskriver at kommunene får pasienter med nye medisinske problemstillinger, kan det indirekte bety en endring i hvilke pasienter som meldes utskrivningsklare.

Dette gir grunn til også å spørre om noe av den reduserte liggetiden som nå er blitt registrert kan skyldes inklusjon av «nye pasientgrupper» i liggetiden for utskrivningsklare pasienter. Det vil være tilfelle om dette er pasienter som tidligere har hatt kortere liggetid enn gjennomsnittet utskrivningsklare.

\section{Mer oppstykket pasient- forløp?}

Et hovedmål for samhandlingsreformen har vært et mer helhetlig pasientforløp $(1,2)$. Studentenes beskrivelser kan tyde på at en del pasienter blir utsatt for et mer oppstykket forløp. Det vanligste forløpet har vært: hjem - sykehus - hjem. Utvidelse av institusjonskapasitet og informantenes beskrivelse av pasientenes behov, gir et bilde av at flere pasienter er blitt tilbudt institusjonsopphold etter innleggelse før de kommer hjem. I noen tilfeller benyttes opphold i et distriktsmedisinsk senter eller en interkommunal intermediæravdeling som alternativ til kommunalt tilbud. Både pasienten og pårørende kan derved få et mer komplekst forløp og betydelig økt antall helsepersonell å forholde seg til. Selv om dette bare skulle gjelde noen få pasienter, representerer gruppen som mottar kommunale tjenester de pasientene som tåler forflytninger og skifte av personell aller minst. Det er også kjent at det er i overgangen mellom tjenestetilbud at økt risiko for feil oppstår $(10,11)$. Men dette må man se i lys av at å bli liggende på sykehus som ferdigbehandlet også har uheldige sider.

Bakgrunnen for økt bruk av institusjonsplasser kan være at utredningene, insentivene og veiledere som er utviklet først og fremst har stimulert til økt bruk av institusjoner. Allerede tidlig i utformingen av samhandlingsreformen var signalene fra myndigheter og andre, at små kommuner trolig ikke ville kunne bemanne og drive tilbudene som det ville bli behov for framover (2). De burde gå sammen om å lage tilbud, underforstått ha tilstrekkelig befolkningsunderlag for å kunne forsvare bygging av institusjoner som for eksempel intermediæravdeling. På samme måte er bevilgningene til å etablere kommunale øyeblikkelig hjelp-døgntilbud knyttet til tilbud etablert $\mathrm{i}$ institusjon (12).

Det kan se ut som om Norge velger en annen vei enn det mange andre vestlige land med de samme utfordringene som oss gjør. Mange velger å satse på en styrking av hjemmetjenester. Begrep i litteraturen som

\section{Kun én kommune fortalte om okt ut- skrivning direkte til hjemmet fra sykehus.}

«hospital at home» og «medical homes» vitner om dette. Satsing på mobile ressursteam og faste kontaktpersoner er det som hyppigst går igjen. Dette omfatter både å yte øyeblikkelig hjelp og oppfølging etter sykehusopphold. Med unntak av noen få pasientgrupper oppnår man like gode medisinske behandlingsresultater hjemme som i institusjon når det gjelder eldre og kronisk syke (13). Når det gjelder rehabilitering oppnås de beste resultatene hjemme (14). Evalueringer viser at man kan oppnå høyere kvalitet, økt pasienttilfredsstillelse og til en lavere kostnad med å organisere tilbud rundt hjemmet (15-17).

\section{Forflytting av «flaskehalser»}

Det er også grunn til å reflektere rundt sykehusenes hyppige forlengelser av bebudet tidspunkt for utskrivning av pasienter. Noen beskrev redusert utnyttelsesgrad på sengeplassene som var satt av til formålet fordi de til dels ble stående tomme. Andre fortalte om korridorpasienter i sykehjemmet. Forskriften om utskrivningsklare pasienter har på sin side hatt som mål å unngå at pasienter som ventet på kommunalt tilbud blokkerer sengeplasser i sykehus. Når det blir rapport at det er blitt lengre ventetid på korttidsopphold og sykehjemsplass, kan det se ut som om en av flaskehalsene i pasientforløpet i sykehus er blitt forflyttet til kommunene. Utskrivningsklare pasienter i sykehus har vært et synlig problem. Omgjøringen av plasser i kommunene og tildeling av plasser til utskrivningsklare

pasienter fra sykehus, framfor hjemmeboende som har behov for institusjonsplass, blir langt mindre synlig.

Man bør vurdere om nåværende ordning med å varsle kommunene om antatt utskrivningstidspunkt er den beste løsningen for å sette kommunene i stand til å forberede mottak av pasientene. Det er tydelig at 
så tidlig varsling er usikkert og skaper problemer. Pasientgruppen som har behov for kommunale tjenester er komplekse pasienter med flere sykdommer og stor risiko for komplikasjoner. De har de lengste sykehusoppholdene; gjennomsnittlig ti dager før de er utskrivningsklare, og med stor variasjon (7). I kommunene peker de også på at pasientopplysningene fra sykehus er mangelfulle. Det er alvorlig, men det er ikke noe nytt $(9,18)$.

\section{$\emptyset$ kt byråkratisering}

Mange kommuner hadde opprettet en 24/7 bestiller-/tildelertjeneste for utskrivningsklare pasienter. I lys av at ingen informanter fra kommunene nevnte at det faktisk hadde inntruffet endringer $\mathrm{i}$ utskrivningstidspunkt for pasienter, og hvis indikerer en kommende vekst av pasientadministrativt arbeid $\mathrm{i}$ kommunene. Som kjent fra sykehus, er også de første døgnene de dyreste. I tillegg til det administrative blir det gjort en ny klinisk utredning med undersøkelser og prøver, for på en trygg måte kunne overta ansvaret og planlegge videre behandling.

Etter hvert som nye helse- og sosialtilbud er kommet til og blitt utbygd i kommunene de siste 50 årene, er de ofte blitt organisert som selvstendige enheter. Når de i tillegg ofte er fysisk atskilte, med separate informasjonssystem og uten felles faglig overbygning, har det medført en betydelig organisatorisk fragmentering av primærhelsetjenesten $(19,20)$. Slik forarbeidet til samhandlingsreformen påpeker er det da vanskelig å få tjenestene til å henge

\section{Sykehjemmet har Faktisk nå opplevd korridorpasienter, noe som var svært sjeldent for.}

det er tilfelle, er en slik investering vanskelig å forsvare med henhold til bruk av ressurser i mange kommuner. Imidlertid, når kommunene oppretter et øyeblikkelig hjelp-døgntilbud, må kommunene ha et døgnåpent mottak av pasienter. Det ble ikke fanget opp noen tilfeller der kommuner samarbeidet om en bestiller-/tildelertjeneste, noe som det er vanskelig å se at ikke skulle være gjennomførbart og lønnsomt.

Beskrivelsene av informasjonsutvekslingen i utskrivningsprosessen fra sykehuset, samt oppretting av nye tjenestetilbud (se over), representerer alle overganger med et stort behov for informasjonsutveksling og dokumentasjon. Dette

godt sammen (1). Når eller hvis de nye kommunale tilbudene blir interkommunale eller opprettes i samarbeid med spesialisthelsetjenesten, betyr det nye enheter atskilt fra de andre kommunale tjenestene og en potensiell aksentuering av problemet med fragmentering. Dette er heller ikke uten betydning klinisk. Mange undersøkelser har vist at organisering av primærhelsetjenesten i større tverrfaglige organisatoriske enheter sammenfaller med bedre helse i befolkningen sammenliknet med områder eller land der dette ikke er tilfelle (21).

\section{Mangelfull informasjons- deling}

Gode pasientforløp omhandler også informasjonsflyt og informasjonstilgang. Mange av informantene ga tydelig tilbakemelding om at manglende eller forsinket utbredelse av elektronisk meldingsutveksling representerte et hinder i gjennomføringen av effektiv samhandling. Et meldingssystem er helt nødvendig for kontinuitet og framdrift i et pasientforløp. Det vil også kunne være en betydelig effektiviseringsgevinst om nødvendig pasientinformasjon ble samlet og knyttet til pasienten, og ikke duplisert i hver enkelt virksomhet slik det skjer nå (22). Samling av informasjonen kan også legge til rette for mer samarbeid uten å måtte forflytte pasienten, og slik redusere faren for feil i overgangene (23). Felles og oppdatert journalinformasjon er viktig, men likevel ikke tilstrekkelig for å få til bedre koordinering av tjenestene (24).

Kritikk av mangelfulle utskrivningsdokumenter og for dårlig beskrivelse av funksjonsevne og samsykdommer hos pasientene, bekrefter det som er blitt beskrevet som et betydelig asymmetrisk partsforhold i samhandlingskjeden (9). For helsepersonell i primærhelsetjenesten er relevant og tilstrekkelig informasjon avgjørende for en trygg og sømløs mottakelse av pasienten. De er helt avhengige av at sykehuset samler inn og overleverer den informasjonen de trenger. Sykehuset er på sin side mest opptatt av informasjonen de selv trenger for å utføre egne oppgaver. Ofte har sykehuset også hovedfokus bare på behandling av én sykdom av gangen, mens pasientene ofte har flere sykdommer (25). I praksis viser det seg at det er kommunen selv som må sørge for å få tilstrekkelig med informasjon ved hyppig og gjentatt 
telefonering. Når en kommune i denne undersøkelsen har gått til det skrittet til selv å møte opp på sykehuset for å kartlegge inneliggende pasienter og beskriver det som en suksess, er det en god illustrasjon på asymmetrien. I noen land har man bøtet på dette problemet ved at sykehusene har ansatt sykepleiere fra primærhelsetjenesten til å lede og organisere utskrivelsesprosessen (26).

\section{REFERANSER}

1. Helse-og omsorgsdepartementet. Nasjonal helse-og omsorgsplan (20112015). Meld. St. 16 (2010-2011). 2010.

2. Helse-og omsorgsdepartementet. Samhandlingsreformen. Rett behandling - på rett sted - til rett tid. St.meld. nr. 47 (2008-2009). 2009.

3. Helse-og omsorgsdepartementet. Forskrift om kommunal medfinansiering av spesialisthelsetjenesten og kommunal betaling for utskrivningsklare pasienter 10/2011. (2011).

4. Norges forskningsråd. Forskningsbasert evaluering av Samhandlingsreformen (EVASAM) for 2012 og februar 2013. Tilgjengelig fra: http://www.forskningsradet.no/servlet/Satellite?c $=\mathrm{Pa}$ ge\&pagename $=$ evasam $\% 2$ FHovedsid emal\&cid=1253972204829. (Nedlastet 14.01.2013).

5. Tjora A. Kvalitative forskningsmetoder i praksis. Gyldendal Akademisk. 2010.

6. Bowen GA. Document analysis as a qualitative research method. Qual Research J 2009;9:27-40.

7. Helsedirektoratet. Kommunal medfinansiering av spesialisthelsetjenesten for 2012 og februar 2013. Tilgjengelig fra: http://www.helsedirektoratet.no/ finansiering/okonomiske-virkemidleri-samhandlingsreformen/kommunalmedfinansiering/tallgrunnlag/Sider/ default.aspx. (Nedlastet 14.01.2013)

8. Hannah DR, Lautsch BA. Counting in Qualitative Research: Why to Conduct it, When to Avoid it, and When to Closet it. J Management Inquiry. 2011;20:14-22. 9. Paulsen B, Romøren TI, Grimsmo A. A collaborative chain out of phase. Int J Integr Care. 2013;13 (14 March): URN: NBN: NL: I: 10-1-114285.

10. Kripalani S, LeFevre F, Phillips CO, Williams MV, Basaviah P, Baker DW. Deficits in Communication and Informa-

\section{KONKLUSJON}

Tiltakene som er iverksatt for å redusere antall pasienter som blir liggende i sykehus i påvente av et tilbud i kommunene, ser ut til å være effektive. Den måten kommunene har løst utfordringen på i første omgang viser imidlertid tegn til å ha noen uheldige sider. Det har medført en økt bruk av institusjoner og en dominoeffekt med økt bruk av hjemmetjenester for andre pasienter. Man ser også tegn til mer oppstykket pasientforløp og mer administrativt arbeid. Et alternativ er i større grad å organisere og stimulere til bruk av hjemmetjenester for øyeblikkelig hjelp og utskrivningsklare pasienter direkte, i stedet for å gå veien om institusjoner. Det foreligger forskning som tilsier at man også bør vurdere organisatoriske tiltak som kan knytte tjenestene i kommunene tettere sammen. tion Transfer Between Hospital-Based and Primary Care Physicians: Implications for Patient Safety and Continuity of Care. Jama. 2007;297:831-41.

11. Midlöv $P$, Bergkvist $A$, Bondesson $\AA$, Eriksson T, Höglund P. Medication errors when transferring elderly patients between primary health care and hospital care. Pharmacy World \& Science. 2005;27:116-20.

12. Helsedirektoratet. Kommunenes plikt til øyeblikkelig hjelp døgnopphold. Veiledningsmateriell. Revidert 01/2013 Oslo: Helsedirektratet; 2013.

13. Shepperd S, Doll H, Angus RM, Clarke MJ, Iliffe S, Kalra L, et al. Avoiding hospital admission through provision of hospital care at home: a systematic review and meta-analysis of individual patient data. Cmaj. 2009;180:175-82.

14. Askim T, Rohweder G, Lydersen S, Indredavik B. Evaluation of an extended stroke unit service with early supported discharge for patients living in a rural community. A randomized controlled trial. Clinical rehabilitation. 2004;18:238-48.

15. Casas A, Troosters T, Garcia-Aymerich J, Roca J, Hernandez C, Alonso A, et al. Integrated care prevents hospitalisations for exacerbations in COPD patients. Eur Respir J. 2006;28:123-30. 16. Dickson G, Mackenzie F. Shifting the balance of care Edinburgh: NHS Scottland 2012. Tilgjengelig fra: http://www. shiftingthebalance.scot.nhs.uk/home/. (Nedlastet 4.12.2012)

17. U.S. Department of Health \& Human Services. Patient centered medical home: Agency for Healthcare Research and Quality. Tilgjengelig fra: http:// www.pcmh.ahrq.gov/portal/server.pt/ community/pcmh__home/1483. (Nedlastet 15.10.2012).

18. Helles $ø$ R, Sorensen L, Lorensen
M. Nurses' information management across complex health care organizations. International journal of medical informatics. 2005;74:960-72.

19. Nolte E, Knai C, Hofmarcher M, Conklin A, Erler A, Elissen A, et al. Overcoming fragmentation in health care: chronic care in Austria, Germany and the Netherlands. Health Economics, Policy and Law. 2012;7 (Special Issue 01): 125-46.

20. Stange KC. The problem of fragmentation and the need for integrative solutions. Annals of family medicine. 2009;7:100-3.

21. Rosano A, Abo Loha C, Falvo R, van der Zee J, Ricciardi W, Guasticchi G, et al. The relationship between avoidable hospitalization and accessibility to primary care: a systematic review. Eur J Publ Health. 2012;DOI:10.1093/eurpub/ cks053.

22. Helse- og omsorgsdepartementet. Én innbygger - én journal. Digitale tjenester i helse-og omsorgssektoren. Meld. St. 9 (2012-2013). 2012.

23. Helse-og omsorgsdepartementet. God kvalitet - trygge tjenester. Kvalitet og sikkerhet i helse-og omsorgstjenesten. Meld. St. 10 (2012.2013). 2012.

24. O'Malley A, Grossman J, Cohen G, Kemper N, Pham H. Are Electronic Medical Records Helpful for Care Coordination? Experiences of Physician Practices. J Gen Intern Med. 2010;25:177-85.

25. Uijen AA, van de Lisdonk EH. Multimorbidity in primary care: prevalence and trend over the last 20 years. The European journal of general practice. 2008;14 Suppl 1:28-32.

26. Van Emden DMD, Ros WJG, Berns MPH. Transition of care: an evaluation of the role of the discharge liaison nurse in the Netherlands. J Advanced Nursing. 1999;30:1186-94. 